\title{
A Study on the Mechanism for Social Organizations to Participate in Social Governance
}

\author{
Wang Hui \\ Weifang University \\ Weifang, Shandong Province, China
}

\begin{abstract}
As an important part of social organizations, social groups are more involved in social governance. Exploring the mechanism for social groups to participate in social governance is conducive to the development of social groups themselves and to the improvement of social gove rnance. Based on the investigation of the status quo of some social groups participating in social governance, this paper analyzes the difficulties and obstacles that social groups face in participating in social governance, and tries to find solutions to these difficulties and obstacles. Drawing on some good experiences and practices, this paper analyzes the key factors (social groups, laws, and government) in the mechanism for social groups to participate in social governance and provides measures with strong practicality and operability.
\end{abstract}

Keywords—social organizations, social governance, mechanism

\section{INTRODUCTION}

In 2014, the 'Decision on Several Major Issues Concerning the Comprehensive Ruling of the Country by Law" passed by the Fourth Plenary Session of the 18th CPC Central Committee stated that it is necessary to give full play to the active role of people's organizations and social organizations in the construction of a society governed by law, and to establish and improve social organizations to participate in social affairs, safeguard public interests, help people in need, help special people, prevent illegal crimes, and institutionalize channels." In 2016, the "Thirteenth Five-Year Plan for National Economic and Social Development" clearly stated: "The role of social organizations should be brought into play, social organization management systems must be perfected, and modern social organizations should be formed with the separation of government and society, the right to be accounted for, and the legal autonomy. ". In 2017, the party's report on the Nineteenth Congress put forward "strengthen the construction of a community governance system, promote the focus of social governance down to the grassroots, play a role of social organizations, and achieve a positive interaction between government governance, social regulation, and residents' autonomy." Social groups have played a positive and beneficial role in economic and social development, the rule by law, and social governance.

Since the reform and opening-up, China's social groups have continued to grow. In terms of the total number, social organizations have increased from 239,000 in 2009 to 336,000 in 2016 (Fig.. 1). From the number of employees in the national social groups, it increased from 320,000 in 2009 to 360,000 in 2014 (Fig.. 2)[1].

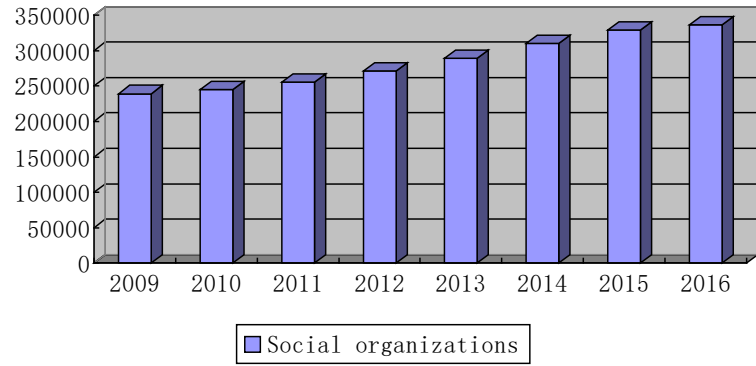

Fig. 1. Changes in the number of social organizations nationwide(2009-2016)

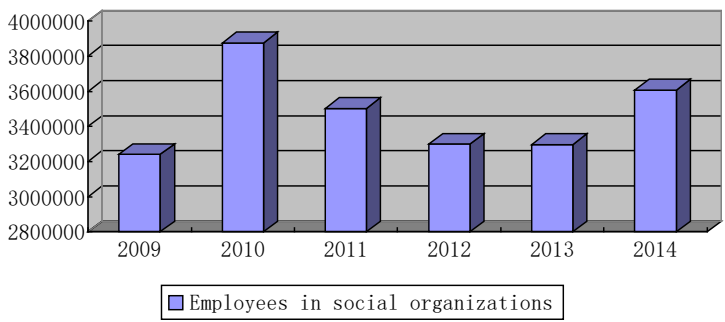

Fig. 2. Changes in the number of employees in social organizations(20092014)

\section{The Status QUO OF Social Organizations Participating in Social Governance}

The author conducted questionnaire surveys and individual interviews with 416 members of social organizations in various industries such as insurance, charity, and education. The results of the survey showed that $7 \%$ of the respondents believe that the role of social groups in exerting social governance is very large; $56 \%$ of them believe that social groups play a relatively large role in social governance; $31 \%$ of respondents believe that social groups play an ordinary role in social governance; $6 \%$ of respondents believe that social groups have little or no role to play in social governance. (Fig. 3) 


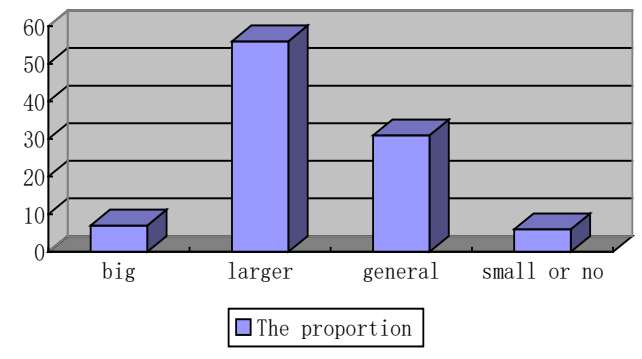

Fig. 3. Survey results of the role of social organizations in exerting social governance

Through survey data and case analysis, it has been found that social groups exert their role in social governance mainly in the following three aspects.

First, social groups are an important force in economic and social development. Social organizations cooperate with the government to perform some social governance functions, and play an important role in regulating the market order, setting industry standards, carrying out scientific and technological innovation, enhancing industry competitiveness, safeguarding social equity, promoting the rule of law, publicizing the party's lines and policies, and training members. For example, in 2018, the number of members of the China Salt Industry Association reached 282. Among them, the vice chairman unit covers 69 salt companies in the province, including Beijing Zhongyan Salt Industry Company and Chongqing Salt Industry (Group) Co., Ltd. China Salt Industry Association summed up six main tasks for 2017: to carry out salt reforms, promote healthy and stable development of the industry; to develop credit systems, promote the integrity of salt companies; to develop electronic tracking system for salt, strengthen salt safety management; to adapt to the reform and development needs of the salt industry, organize salt industry exhibitions; to play a bridge role of the Association, serve the industry and enterprise in good faith; to strengthen party building work, strengthen the association itself.

Second, social groups are a useful complement to social management and public services. Social organizations have become an integral part of social management by improving service levels, enhancing industry self-discipline, and conducting social research; social organizations provide effective public service by participating in government projects, organizing participation in charity service activities, helping vulnerable groups, and resolving social conflicts and so on. For example, the official website of China Charity Federation has announced the amount of funds raised over the years (Fig. 4). The amount raised in 2007-2013 has increased by 8 times. China Charity Federation's 2016 limited annual donation income is as high as 18.7 billion, which is earmarked for projects such as disaster relief, student education, medical assistance, old-age assistance, and poverty assistance.

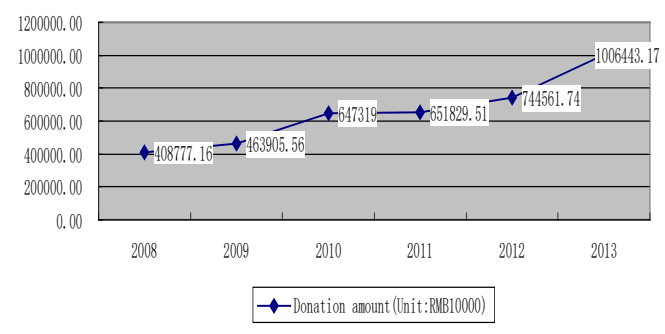

Fig. 4. Donation amount of China Charity Federation

Third, social groups are the bridge and link between the government and society. Social groups have broadly united their active forces in various fields to gather wisdom from all sides, understand public appeals, help the public, especially members, safeguard their rights and interests, and serve as a bridge and link between the government and society. Social organizations are the main force of non-governmental exchanges. Members cover a wide range of industries and regions. They use opportunities such as investigations, exchanges, and study to develop a variety of nongovernmental exchange activities in various forms. In 2017, the Consumers Association of China accepted a total of 726,840 complaints from consumers, and revolved 552,398 among them. The complaints resolution rate was $76 \%$, and the consumers recovered RMB 516.39 million in economic losses. Among them, the compensation amount in 4,898 complaints was doubled due to fraudulent acts by the operators, and the compensation amount was doubled by 8.25 million. In the whole year, it received 1.21 million visits and consultations from consumers. The joint news media exposed exposures to businesses that were lack of integrity and provided clues for the special rectification activities of the industry and commerce and taxation departments. It has become a bridge and link to reflect consumer appeals, supervise corporate behavior, and assist the government.

\section{DIFFICULTY AND OBSTACLES FACED By SOCIAL GROUPS When PARTICIPATING IN SOCIAL GOVERNANCE}

There are still many problems with the participation of social organizations in social governance and they face many difficulties and obstacles. A survey of members of social organizations found that most respondents expressed dissatisfaction with the status quo of social organizations participating in social governance. When asked about "what difficulties do social organizations face in participating in social governance?” respondents gave many ans wers. (Table 1)

TABLE I. DIFFICULTIES AND OBST ACLES FACED BY SOCIAL GROUPS WHEN THEY PARTICIPATE IN SOCIAL GOVERNANCE

\begin{tabular}{ll}
\hline Difficulties and Obstacles & $\begin{array}{l}\text { The proportion of respondents selected } \\
\text { this item }\end{array}$ \\
\hline $\begin{array}{l}\text { Insufficient government funding } \\
\begin{array}{l}\text { The government's management of } \\
\text { social groups is incomplete }\end{array}\end{array}$ & 31.2 \\
$\begin{array}{l}\text { Lack of laws, regulations, and } \\
\text { institutional guarantees }\end{array}$ & 44.1 \\
$\begin{array}{l}\text { Unbalanced development of social } \\
\text { groups }\end{array}$ & 48.7 \\
$\begin{array}{l}\text { Inadequate internalmanagement of } \\
\text { social groups }\end{array}$ & 31.5 \\
\hline
\end{tabular}




\begin{tabular}{ll}
\hline \multicolumn{1}{c}{ Cont. to TABLE I } \\
\hline $\begin{array}{l}\text { Insufficient motivation for social } \\
\text { groups to participate in social }\end{array}$ & 30.1 \\
$\begin{array}{l}\text { governance } \\
\text { Social groups lack independence }\end{array}$ & 27.4 \\
$\begin{array}{l}\text { People's recognition of social groups is } \\
\text { not high }\end{array}$ & 19.9 \\
Socialgroup members are unstable & 17.3 \\
Other & 9.5 \\
\hline
\end{tabular}

It can be seen that the difficulties faced by social groups in participating in social governance are mainly concentrated in three aspects:

First, the social community related laws need to be improved. At present, the construction and management of social organizations is based on the "Regulations on the Registration of Social Organizations”. It's also based on rules and regulations such as, the "Regulations on Administrative Punishment Procedures of Social Organization Registration Administration Authorities" and the "Regulations on Income Tax Collection of Business Institutions, Social Organizations, and Private Non-corporate Enterprises", the "Regulations on the Adjustment of Associations", the "Regulations on the Regulation of Issues concerning Social Organizations for Cooperation Activities", and the "Measures for Registration of Branches of Social Organizations and Representative Institutions".

Second, the government management system is not perfect. On the one hand, the management methods of social groups are single; administrative methods such as management registration are the main methods; legal and economic means are not used sufficiently; the socialization of social services is not high. On the other hand, the government has invested insufficient resources and some of the preferential policies and support policies that have been formulated need to be further implemented.

Third, the development of social groups is not balanced and their vitality is insufficient. Social organizations with an official background are stronger, more standardized, and more funded. For instance, the China Charity Federation has received strong support from the government and has developed rapidly. Civil society groups generally have problems such as unstable personnel, lack of funds, and lack of innovation in work. Public recognition of some social groups is not high, making it difficult for social groups to raise funds and win projects.

\section{EXPLORATION OF THE MEChanism FOR SOCIAL GROUPS tO PARTICIPATE IN SOCIAL GOVERNANCE}

First, strengthening the construction of laws, regulations and systems to provide guarantees for social organizations to participate in social governance.

Establish and improve the relevant laws and regulations of social organizations and promote the development of social groups as soon as possible into the path of standardization and legal development.

The "Regulations on the Registration of Social Organizations"[2] stipulates the requirements for entry barrier. At present, the "Regulations on the Registration of Social
Organizations" stipulates that there are a number of conditions for the establishment of social organizations (individuals are required to be more than 50 , units are required to be more than 30), organizational restrictions, site restrictions, full-time staff restrictions, funding restrictions (national social groups are required to have more than 100,000 yuan as the activity funds, and local social organizations are required to have more than 30,000 yuan as the activity funds) and responsibility restrictions. This barrier is too high, which can easily lead to the transformation of some groups into underground organizations. It is proposed to revise the requirements related to entry barrier in 'Regulations on the Registration of Social Organizations", and to appropriately lower the requirements in terms of the number of people and activities funds.

Raise the level of legislation. At present, "Regulations on the Registration of Social Organizations" and other laws are relatively low, and a relatively high level of legislation is required to fully define the definition, characteristics and establishment conditions of social groups. The legislation should also include the following aspects: clarify the relationship between the government and social organizations, further affirm the legal responsibilities of social groups, safeguard the dominant position of social organizations in the participation in social governance, and clarify the rights and obligations of social groups; The responsibility of social groups is that social organizations must serve the community on the one hand and perform some of the government's administrative functions on the other. If the use of power is improper, it will weaken the credibility of the government. Therefore, it is necessary to clarify the legal responsibilities of social groups in the law.

Second, dealing with the relationship between social groups and the government and stimulating the participation of social groups in the vitality of social governance.

The main resources and responsibilities for social governance are in the hands of the government. The role of social organizations in social governance should be brought into play, and it is critical to establish a cooperative and cogovernance between social groups and the government.

The government must authorize social organizations. With the transformation of government functions, some functions must be transferred to the market and social organizations. Social groups have become one of the main bodies for the transfer of government functions. In 1999, the State Economic and Trade Commission issued the "Some Opinions on Accelerating the Cultivation and Development of Industrial and Commercial Sector Associations." It pointed out that in addition to its functions of service for enterprises and the functions of self-regulation, coordination, supervision and maintenance of the legitimate rights and interests of enterprises, the Industrial and Commercial Association has the function of assisting government departments in strengthening industry management, and put forward 17 specific functions, including conducting investigation and research, organizing exhibitions, reflecting member requirements, and being authorized by government departments to participate in the formulation of industry plans. Some public interest groups can take on more social governance responsibilities in non- 
administrative functions, such as public service outsourcing and assistance in policy implementation.

The government directly supports social organizations. In order to nurture social groups, the government can fund the development of social groups in various ways, including direct financial support, build platform mode, purchase services. "Government purchase of public services is an important source of funds for social organizations, and on average accounts for $50 \%$ of the total income of social organizations. More than $80 \%$ of the welfare institutions in Hong Kong, China are social organizations."[3] According to the list of municipal social organizations that are publicly available to undertake the transfer of government functions and purchase services, the number of social organizations accounts for about $40 \%$ of the total number of social organizations. Government departments select eligible social organizations through declaration, review and inspection to ensure the quality of services purchased.

Expand channels to build a platform for social organizations to participate in social governance. Improve the party committee and government decision-making consultation mechanism. Before making major decisions involving industry or public interest, we should absorb relevant industries or fields of social organizations to participate in consultations, hearings, and demonstrations; Improve the information reporting system for social organizations so that opinions and suggestions of social organizations can be channeled to the decision-making organs; innovate the public service supply mechanism, guide social organizations to provide quality and efficient public services based on social needs, and form a diversified and multi-level public service supply pattern. [4]

Third, regulating the internal construction of social organizations and enhancing the ability of social groups to participate in social governance

In accordance with the objectives of a clear legal person status, a sound governance structure, a stable financing channel, a sound control mechanism, and a scientific management operation, the internal management of social organizations should be improved.

Establish a sound internal system. Improve the financial system, implement the principle of "unified leadership, centralized management," and deal with different types of social groups in financial management. For mutual benefit social groups, their finances must be supervised by all members; public welfare social groups should refer to the management of the foundation and improve their information disclosure and disclosure systems. Improve the electoral system, and in accordance with the provisions of the articles of association, solicit opinions, democratic consultations, and hold expert consultation meetings before making major policy decisions, so as to ensure the scientific and democratic decision-making mechanism for elections. Improve the employment system, broaden the scope of the selection, establish a staff employment system, training system, management system, and scientific and effective reward and punishment mechanism. Improve the branch management system, establish branch management methods, supervise and manage branch operations, and strictly manage registration management, organization management, and event management.

Establish a scientific and rational organizational structure. A sound organizational structure, standardized rules of procedure, and democratic decision-making procedures are important prerequisites for improving internal governance. Any decision made by a social organization should be conducted according to a certain democratic procedure, thus restricting the excessive concentration of power and guaranteeing the legitimacy, rationality, and scientificness of the decision. The social organizations must be based on the statutes, and improve the organizational structure, that is the authority-the member representative assembly or general assembly, the implementing agency - the board of directors, the standing council. Further improve the president's office meeting system.

\section{CONCLUSION}

All in all, the degree of participation of different regions and social groups in social governance is not balanced. This is closely related to the local government's management system, the internal construction of social groups, and the improvement of laws and regulations. The government can only stimulate the vitality of social groups if it takes the initiative to reform and innovate, "focuses on certain tasks while puts others aside" in the management of social groups. Social groups can only take a place in social governance if they are brave enough to take the initiative and change. It can be believed that with the deepening of state reforms, social groups will play an increasingly important role in social governance.

\section{REFERENCES}

[1] Lai Xiandong, Wang Dengli.An Empirical Study on the Influencing Factors of Social Organization Development - Based on the analysis of 31 provincial panel data from 2007 to 2014. Management Review, December, 2017.

[2] Geng Huang.Social Organization Development and Reform Observation. Chinese Civil Affairs, July, 2014.

[3] Li Chongyi. Government Purchasing Services and Development of Social Organizations - Taking the Social Organization Service and Development in Zhejiang Province as an Example. Chinese Social Organization, January, 2011.

[4] Ma Fuyun.People's Group Participates in Social Governance. Journal of the Central Institute of Socialism, April, 2014. 